\title{
CIRCUNSTÂNCIAS FAVORECEDORAS DO PROTAGONISMO DO PODER JUDICIÁRIO DO DEBATE E SOLUÇÃO DE QUESTÕES POLÍTICO- SOCIAIS
}

\section{CIRCUMSTANCES FAVORING THE JUDICIARY IN THE DISCUSSION AND SETTLEMENT OF POLITICAL AND SOCIAL ISSUES}

\author{
${ }^{1}$ Lilian Muniz Bakhos \\ ${ }^{2}$ Patricia Cristina Vasques De Souza Gorisch
}

\section{RESUMO}

O presente estudo faz uma análise pontual sobre as circunstâncias que favorecem o importante papel atualmente desenvolvido pelo Poder Judiciário na efetivação dos direitos sociais, na proteção dos interesses das minorias e no debate político, focando especialmente na crise de representatividade e na crescente onda de redemocratização - marcas da atualidade nacional.

Palavras-chave: Ativismo judicial, Direitos fundamentais, Judicialização de políticas públicas

\section{ABSTRACT}

This study is a specific analysis of the circumstances favoring the important role currently developed by the judiciary in the enforcement of social rights, protecting the interests of minorities and political debate, focusing especially on the crisis of representation and the rising tide of democracy - trademarks of the national crisis.

Keywords/Palabras-claves/Mots-clés: Judicial activism, Fundamental rights, Legalization of public policies

\footnotetext{
${ }^{1}$ Doutoranda em Direito pela Universidade Católica de Santos. Advogada. UNISANTOS, Santos. Brasil

E-mail: lilian@ybs.adv.br

2 Doutoranda em Direito Ambiental Internacional pela Universidade Católica de Santos. Docente da Universidade Católica de Santos. Universidade Católica de Santos - UNISANTOS, Santos. Brasil

E-mail: patricia@patriciagorisch.adv.br
} 


\section{INTRODUÇÃO}

Inegavelmente a sociedade mudou - e o Direito evoluiu para atender a esta mudança social. Dentre outras adequações, merece destaque a ampliação da atividade jurisdicional, que deixa de restringir-se à mera revelação do texto abstrato da lei a um caso concreto e passa a atender aos anseios da comunidade redemocratizada.

A complexidade das relações sociais entre particulares e perante o Estado, bem como o crescente pluralismo ideológico fizeram com que a antiga postura do Poder Judiciário deixasse de atender às necessidades sociais, especialmente em relação a direitos fundamentais que dependessem de uma postura governamental ativa.

A fim de tornar efetivas as normas constitucionais que a todos se impõem, juízes e tribunais tiveram seus poderes ampliados e passaram a buscar fundamento constitucional para as suas decisões, intentando realizar justiça nos casos que lhes são apresentados, seja diante de uma lesão já concretizada a direitos fundamentais, seja em relação a ameaças, assumindo uma postura preventiva sempre que preciso.

Agindo assim, o Judiciário passa a exercer maior controle sobre os atos das instâncias representativas e estabelece balizas a serem obedecidas pelas autoridades públicas.

A esta atual postura proativa do Poder Judiciário deu-se o nome de ativis mo judicial ou protagonismo judicial.

O presente artigo aborda as causas que favorecem a atual e crescente participação do Poder Judiciário brasileiro em debates políticos. Dentre estas causas, mereceram destaque neste estudo a crise do Estado Moderno e a perda de credibilidade nas instâncias representativas (que deixaram de corresponder à vontade do povo ou da maioria que os elege), além da onda de conscientização popular acerca dos direitos que todos os indivíduos titularizam e de sua justiciabilidade (ou seja, a possibilidade de serem cobrados em juízo), e o aumento dos anseios contramajoritários, típico resultado do pluralismo social. 


\section{DIREITO E POLÍTICA: UMA RELAÇÃO DE COMPLEMENTARIEDADE}

Direito e política não se confundem, mas podem ser considerados como dois lados de uma mesma moeda. A Constituição tem o relevante papel de fazer a interface entre estes dois universos, constituindo o Estado Constitucional Democrático: é ela distingue e distribui as competências para legislar e administrar - típicas da esfera política - e para julgar, construindo para esta um espaço autônomo e independente.

O poder constituinte originário, "energia política em estado quase puro" (BARROSO, 2011), instituiu os Poderes de Estado e lhes distribuiu competências diversas. Ao Legislativo confere a função precípua de criar o direito e fiscalizar a administração pública; ao Executivo determina a condução das políticas públicas e, finalmente, ao Judiciário confere a atribuição de aplicar o direito em casos de conflitos de interesses.

Se ao Legislativo e Executivo a Constituição Federal reserva competências essencialmente políticas tornando-os em instâncias nas quais desenrolam-se, por excelência, os debates das maiorias, ao Poder Judiciário delega funções fundamentalmente técnicas, a serem exercidas por membros não eleitos, cuja finalidade é garantir a observância das regras procedimentais e da licitude do conteúdo desta atuação política.

Na política prevalece o domínio da vontade, a soberania popular, o princípio majoritário. No direito, por sua vez, vigora o domínio da razão, a primazia da lei e o respeito aos direitos fundamentais. Pode-se notar que são campos distintos, com peculiaridades evidentes e finalidades diversas, mas, ainda assim, são complementares. (BARROSO, 2011)

Aliás, mais do que uma relação de complementariedade, direito e política mantém entre si grandes e importantes pontos de intersecção. Veja-se, por exemplo, que a criação do direito é um dos mais genuínos frutos do processo político (constituinte originário ou legislativo) - nasce da vontade da maioria por meio da atuação de quem a representa politicamente. 
A ideia de que existe uma nítida e estável fronteira entre direito e política sucumbe diante da realidade dos Estados democráticos que, para sua existência e manutenção, reservam parte do poder político ao Judiciário, que o exerce por membros não eleitos e, portanto, salvaguardados do escrutínio popular. A referidos membros é delegada a competência para resolver embates que envolvem a validade dos atos estatais (que, nesta condição, nada mais são do que atos conduzidos de acordo com a vontade da maioria da sociedade) e sua compatibilidade com os valores prescritos pelo constituinte originário.

Para que possa atuar de forma imparcial, sem sofrer as influências que circundam o campo político, a Constituição Federal concede à Justiça dois grandes instrumentos: a independência em relação às demais instâncias de governo ${ }^{1}$ e sua vinculação ao direito a atuação dos juízes e tribunais está sempre pautada pelos mandamentos constitucionais e legais ${ }^{2}$.

As normas jurídicas, todavia, não trazem em si um conteúdo objetivo ou um sentido único válido para todas as situações sobre as quais incidem. Do ponto de vista da teoria jurídica contemporânea (especialmente da teoria neoconstitucionalista e seu viés pós-positivista) já se consente que a aplicação da lei envolve elementos cognitivos e volitivos. Se assim é, ao Poder Judiciário - intérprete final do direito - cabe determinar o sentido e alcance da Constituição e dos ordenamentos infraconstitucionais, vinculando, inclusive, os demais Poderes.

Há, portanto, uma supremacia judicial quanto ao estabelecimento do que seja o direito, fato que evidentemente denota a existência de poder político também na esfera jurídica.

Esta participação na seara política, porém, pode dar-se de forma mais ou menos intensa, a depender das circunstâncias e do momento em que vive a sociedade.

\footnotetext{
1 Independência financeira, autonomia administrativa, nomeação por critério meritório, vitaliciedade, inamovibilidade e irredutibilidade de vencimento de seus membros.

2 Ainda assim não é correto afirmar que o Poder Judiciário es capa do esquema de "frios e contrapesos" inerente às democracias modernas. Apesar de sua independência e autonomia em relação aos demais Poderes, o Judiciário submete-se ao controle adminis trativo, financeiro e dis ciplinar do Conselho Nacional de Justiça, instituído pela EC 45/04.
} 
Atualmente (e especialmente no Brasil), vem se notando uma crescente participação da Justiça na resolução de questões eminentemente políticas, o que tem gerado certo desconforto doutrinário e algum alvoroço crítico ${ }^{3}$.

Tamanha a sua relevância, os motivos que favorecem a atuação política do Poder Judiciário (com ênfase para as interferências judiciais na elaboração e/ou condução de programas sociais, principalmente nos casos de inércia e ineficácia governamental) passam a ser foco específico de análise no presente estudo. Destacam-se, a seguir, aquelas eleitas como principais, ressaltando-se que não há a pretensão de esgotá-las.

\section{Crise do Estado Moderno e a perda da credibilidade nas instâncias representativas.}

O poder crescente da Justiça oculta uma de suas principais causas: o enfraquecimento do Estado.

Pode-se relacionar o protagonismo judicial à incapacidade que as instâncias representativas têm demonstrado, até então, de resolver os problemas crescentes e complexos da sociedade atual e de garantir proteção aos anseios sociais - quase sempre prevista na Constituição Federal -, o que leva o Judiciário a se mostrar como um canal possível e satisfatório para sua solução de conflitos.

A atual crise de funcionalidade do legislativo e a má gestão administrativa refletem poderes inoperantes. E todo Poder não exercido (ou mal exercido) deixa um vácuo que é prontamente preenchido por outro Poder.

\footnotetext{
${ }^{3}$ Como exemplo, cite-se o posicionamento de Elival da Silva Ramos, estudioso do tema, que se mostra contrário ao ativis mo e à judicialização por entender que resultamemuma dis função do Poder Judiciánio e ursupação da competência legislativa. As providências políticas devem ser tomadas pelo Congresso Nacional, não pelo Poder Judiciário, sob pena de caracterizar-se interferência indevida no Legis lativo e Executivo, o que acarreta desequilíbrio inadmis sível entre os três Poderes. In:Democracia desequilibrada. Dis ponívelem < http://www.conjur.combr/2009-ago-01/entrevis ta-elival-silva-ramos-procurador-estadosao-paulo>. Acesso em: 08/04/2016
} 
Tal fato pode ser constatado historicamente: desorganizados o Legislativo e o Judiciário, prevalece o poder do Executivo e suas determinações vinculam o legislador e calam as vozes dos magistrados; com a tomada do poder pelo parlamento, este torna-se o principal ator do cenário político e suas leis relegam participações menos expressivas ao Executivo (que apenas cumpre suas determinações) e ao Judiciário (que se limita a aplicar, ipsis litteris, o texto de lei ao caso concreto); finalmente, pode-se concluir que diante da inoperância e da diminuição dos poderes Executivo e Legislativo, tende a inflarse o Poder Judiciário.

De fato, a atuação política do Poder Judiciário nunca esteve tão nítida e frequente como na atualidade. Julga-se que esta intensificação decorre, principalmente, de dois fatores: (a) o pluralismo das sociedades, que torna complexa a convivência em sociedade e gera maior procura pelas instâncias judiciais para a resolução de desacordos morais; e (b) a crescente desconfiança da sociedade em relação aos Poderes Legislativo e Executivo (PAULA, 2011)

Com a força normativa da Constituição Federal, a amplitude de seus princípios e a possibilidade de utilizá-la para fundamentar pretensões na esfera judicial, uma única pessoa é capaz de brigar contra e derrotar o Estado. Diante do Poder Judiciário, um único cidadão pode debater, em igualdade de condições perante o Poder Público, questões relevantes para um determinado grupo e, inclusive, para toda a coletividade.

Diante desta possibilidade, aumenta também o distanciamento entre os cidadãos e as instituições que têm por função precípua a representação dos grupos sociais. Perdem força, por exemplo, os sindicatos e os partidos políticos, o que torna cada vez mais difícil a defesa dos interesses coletivos por meio deles. Sem apoio popular e sem força política para satisfazer os anseios do grupo, as instituições já enfraquecidas vão, aos poucos, definhando e perdendo sua razão de ser.

Isto ocorre nitidamente no Brasil. Aqui o processo majoritário demonstra claramente suas imperfeições: os representantes do povo atuam, muitas vezes, apenas em favor de seus próprios interesses ou do pequeno (e poderoso) grupo que garante sua manutenção no sistema. 
É certo que, na medida do possível, todo agente público deve atuar em prol do bem comum, mas manter a retidão diante do mar de tentações em que vive afundado nosso sistema político parece ser difícil e parcela significativa dos agentes políticos eleitos acaba se utilizando da máquina estatal para alcançar fins de interesse pessoal ${ }^{4}$, legítimos ou ilegítimos. Constrói-se, desta forma, um sistema especialmente desfavorável às minorias (que, em verdade, pode representar a maioria numérica) sem expressividade política.

Reconhece-se, talvez por unanimidade, que o "iter legislativo brasileiro é repleto de falhas e problemas, que vão de sua estrutura normativa aos interesses pessoais em jogo" (PIRES, 2011) e todos estes desvios tendem a transparecer um Poder incapaz de dar respaldo às necessidades sociais.

A sociedade, de forma geral, não confia mais no autocontrole das instâncias representativas e no senso ético dos agentes políticos eleitos. E é justamente esta confiança que legitima a atuação destes Poderes: sem ela a engrenagem do sistema democrático e republicano emperra.

O sistema republicano exige um efetivo e eficaz controle dos agentes públicos para que não transformem seus empregos, cargos ou funções em postos de tutela de interesses egoísticos. Frise-se: a renúncia ao autofavorecimento e à arbitrariedade não é uma exigência moral, mas um pressuposto da existência de um verdadeiro sistema republicano (GRIMM, 2006)

No Brasil, as inúmeras notícias de desvirtuamento ou abuso de função dos agentes políticos $^{5}$ promovem a descrença geral da população em relação à política majoritária, ao Congresso Nacional (generalizadamente) e aos partidos políticos.

\footnotetext{
${ }^{4}$ Como, por exemplo, votos, participação emesquemas de des vio de dinheiro público, benefícios em seu regime funcional, vantagens remuneratórias, entre outros.

${ }^{5}$ Cite-s e como exemplo os dois primeiros anos de mandato da atual Presidente da República, nos quais oito de seus minis tros entregaram o cargo após envolvimento emes cândalos públicos e denúncias de corrupção. Da mes ma forma, as denúncias feitas às vésperas da eleição presidencial de 2014 sobre a exis tência de um esquema de corrupção na Petrobrás, envolvendo pessoalmente os candidatos e/ou seus aliados. Notícias disponíveis, respectivamente, em < http://www.estadao.combr/especiais/os-ministros-que-cairamdurante-o-governo-dilma,146906.htm > e < $\quad<$ http://g1.globo.com/jornal nacional/noticia/2013/08/en genheiro-denuncia-esquema-de-corrupcao-na-petrobras-para-favorecer-pmdbe-pt.html>. Aces so em 06.04.2016.
} 
Desenvolveu-se uma percepção geral de que a política parlamentar e partidária move-se apenas e exclusivamente em torno de interesses escusos e egoísticos, consubstanciando-se como esferas irremediavelmente corrompidas.

Se de um lado a população perde a crença na capacidade e seriedade das instâncias representativas, por outro lado sua confiança no Poder Judiciário vem se fortalecendo na medida em que este profere decisões que, em sua maioria ${ }^{6}$, encontram-se em consonância com a opinião pública.

A busca pela jurisdição é, então, resultado de um ato de defesa da sociedade contra a crise política contemporânea. O sujeito que já não se vê representado pelas esferas de governo busca na Justiça um apoio a favor de seus interesses. E, muitas das vezes, ali o encontra.

Importante perceber que a crise de representatividade não é o único motivo da descrença popular nas esferas governamentais. Em certas situações, os próprios atores políticos preferem que o Judiciário seja a instância decisória, especialmente no caso de questões polêmicas e sobre as quais haja desacordo moral na sociedade, a exemplo das deliberações sobre uniões homoafetivas, interrupção de gestação de feto anencéfalo, demarcação de terras indígenas, possibilidade de pesquisas com células-tronco embrionárias, entre outras.

Transferindo à Justiça a obrigação de determinar a solução ideal destas questões que causam inquietude social e sobre as quais não se vislumbram posições majoritárias, as instâncias representativas evitam o custo de um processo legislativo e a pressão midiática e popular, além de afastar o risco do próprio desgaste (BARROSO, 2011).

6 STF, RE 633.703. Nem sempre a atuação do Poder Judiciário reflete a vontade popular. Exemplo disso foi a decisão do STF no sentido de impedir a aplicação da Lei da Ficha Limpa (LC 135/2010) às eleições do ano de 2010. A lei foi frut o de iniciativa popular e havia forte pressão social para que ela produzisse efeitos de imediato, inclusive em relação às eleições em curso. Apesar do nítido e legítimo interesse social na imediata aplicação da lei, o STF, em prol da integralidade do art. 16, CF/88, contrariou a expectativa popular e julgou a lei complementar inaplicável às eleições daquele ano. 
Trata-se de uma estratégia dos Poderes Legislativo e Executivo que, por meio de uma inércia deliberada, possibilita a atuação ativista dos tribunais. Temas conflituosos e profundamente controvertidos, em relação aos quais não se tem perspectiva de consenso na sociedade, são apoliticamente custosos e, por esta razão, há uma tendência em entregálos à análise daqueles que não precisam passar pelo crivo do voto popular após suas decisões.

Como consequência, quase todas as questões de relevo político passam a ser debatidas e solucionadas perante o Poder Judiciário que firma, com isso, sua imagem de órgão salvador da pátria.

A crise do Estado moderno tende a se agravar caso as circunstâncias fáticas permaneçam idênticas às atuais. Se o Poder Executivo e o Poder Legislativo continuarem a minguar por sua inoperância e má gestão, permitindo que suas ações continuem se afastando da vontade social, o Poder Judiciário tende a crescer ainda mais, evidenciando sua indiscutível faceta política.

\section{Democracia e redemocratização. A consciência de direitos}

Desde a Antiguidade, em sua clássica obra A Política, Aristóteles já definia a democracia como o governo da maioria - ao lado da monarquia (governo de uma única pessoa) e da aristocracia (governo de um pequeno grupo ou minoria).

A partir de então, consolidou-se firmemente a ideia de que a direção geral dos interesses da coletividade compete à maioria do povo que, participa efetivamente do governo, seja pela forma direta, seja pelo sistema representativo.

Todavia, a democracia impõe um conteúdo substancial ao governo da maioria: este deve ser dar em uma ordem constitucional que reconheça e garanta os direitos fundamentais dos indivíduos. Conforme afirma MALUF (2008):

“...são objetivos da democracia, em suma,
eliminar o pauperismo, a insegurança, o


desemprego, os mocambos rurais e urbanos; criar oportunidades para a juventude; estabelecer padrões básicos para uma vida decente e, de envolta com estas finalidades, assegurar a preservação dos valores humanos".Sem que esteja consolidado este ambiente democrático, ainda que o governo tenha origem popular, ele será apenas formalmente democrático, mas nunca o será quanto ao seu exercício. $\mathrm{E}$, dentre os dois aspectos da democracia, merece maior atenção o substancial, que deve permear toda a ação social, política e econômica do Estado.

O rótulo de "poder emanado do povo" já não serve mais para justificar governos tiranos, autoritários ou ditatoriais. Ainda que um determinado governo tenha sido regularmente instituído pela vontade da maioria, este fato não terá aptidão para afastar o ideal democrático presente na consciência coletiva, que naturalmente inflamará a massa a reagir e retomar seu poder. ${ }^{7}$

Dependente da existência de uma Constituição escrita que declare e crie mecanismos de garantir os direitos fundamentais, a democracia pressupõe, com igual relevância, a obrigatoriedade de se equipar o Estado para que possa efetivá-los. Um Estado, para classificar-se como democrático, deve ter como finalidade a diminuição das desigualdades humanas, a garantia da supremacia da Constituição como expressão da vontade popular e a submissão de seus agentes a princípios da responsabilidade e da moralidade, pressupostos de validação de seus atos.

Neste ponto, cabe esclarecer que um regime democrático deve promover a igualdade entre os indivíduos sob quatro enfoques: (i) igualdade jurídica, caracterizada pela inexistência de tratamento discriminatório por motivos de gênero, cor, raça, religião, status social, ideologia ou qualquer outro critério que afronte a dignidade humana; (ii)

\footnotetext{
${ }^{7}$ Nesse sentido, Sahid Maluf cita como exemplos de usurpadores do poder popular sob o rótulo de democracia: Napoleão (que denominava seu governo de Império democrata); Hitler (e sua Democracia autoritária); Mussolini (que defendia que o facis mo era uma democraciaproletária); Lenin e Stalin (que instituíram na Rússia uma Democracia socialista). Em tempo relativamente curto, todos estes ditadores caíram - e tantos quanto surgirem igualmente, cairão - pela impossibilidade de supressão de direitos inatos ao homem eternos e superiores à vontade daqueles que exercem o poder. Obr. Cit.
} 
(ii) igualdade de sufrágio, representada pelo voto unitário, com mesmo valor para todos, o que impede a sobreposição de um grupo social em relação a outros; (iii) igualdade de oportunidade, que se verifica, por exemplo, na idêntica possibilidade de acesso à cultura, educação, mercado de trabalho, funções públicas; e (iv) igualdade econômica, traduzida, principalmente, pelo estabelecimento e garantia a todos os indivíduos de um padrão

mínimo de condições dignas de vida.

Conclui-se que não basta que a democracia se mostre como uma ordem assecuratória de direitos políticos; é imprescindível que ela oriente o Estado a buscar condições materiais mínimas para que seu povo possa, efetivamente, exercer o poder que dele emana. Homens economicamente miseráveis, expostos a condições indignas de trabalho, moradia e saúde, que empenham toda sua força em sobreviver, não tiram nenhum proveito de uma eventual (e, neste contexto, ficta) igualdade jurídica, de sufrágio ou de oportunidades. Não há democracia se o povo é um soberano faminto, descalço, analfabeto, doente.

Importante frisar que a igualdade econômica da qual depende a democracia não significa o nivelamento financeiro, mas apenas o estabelecimento de um padrão mínimo vital que deve ser assegurado pelo Estado mediante políticas públicas e sociais.

Ao Estado cabe a função de elaborar leis garantidoras da igualdade entre os cidadãos e aplicá-las visando a este fim. Sob pena de violação à democracia, o Estado deve criar um cenário social favorável, possibilitando a todos as mesmas oportunidades e as mesmas condições de aproveitá-las.

É de se ressaltar que a definição de democracia como sendo o governo da maioria é um mito diante da realidade nacional. A ordem constitucional pátria prevê que o corpo eleitoral é formado apenas pelos cidadãos, ou seja, pelas pessoas que exercem regularmente, seus direitos políticos. 
No censo demográfico realizado pelo IBGE em 2010, constatou-se que a população nacional é de 190.732.694 habitantes ${ }^{8}$. Destes, em 2014, apenas 142.822.046 são cidadãos exercentes de seus direitos políticos e, portanto, potenciais eleitores. Dos cidadãos que compõem o corpo eleitoral, apenas 54.501.188 votaram na candidata eleita Presidente da República nas eleições de outubro de $2014 .^{9}$

Com base nos dados apresentados, pode-se afirmar que o povo brasileiro (composto por mais de 190 milhões de habitantes) é representado politicamente de acordo com a vontade de um grupo que equivale a pouco mais de $74 \%$ da população total. Mais de um quarto dos indivíduos não participa do processo eleitoral e, ainda assim, a vontade prevalecente entre o restrito grupo daqueles que possuem e exercem seu direito de voto é tida como a vontade do povo. ${ }^{10}$

O governo do povo, como demonstrado, é um conceito legal e ideal, não uma realidade. E, se o critério quantitativo já não cumpre sua função de, efetivamente, garantir que o Estado seja conduzido por diretrizes traçadas pela maioria da sociedade, é preciso que haja maior preocupação com a capacitação do corpo eleitoral, para evitar que impere a vontade de uma massa inculta e miserável, vítima potencial de crimes eleitorais como o de compra de voto e outras formas de captação ilícita de sufrágio. ${ }^{11}$

8Informações disponíveis em:

$<\mathrm{http}: / /$ saladeimprensa.ibge.gov.br/noticias?view=noticia\&id=1 \&idnoticia=1766\&busca=1 \&t=cen so-2010-populacaobrasil-190-732-694-pessoas>. Acesso em 08.04.2016

9 Informações disponíveis em: <http://placar.eleicoes.uol.com.br/2014/2turno/>. Acesso em 08.04.2016

10 Em relação a este tema, cabe ainda lembrar que o resultado das eleições é apurado, geralmente, por maioria relativa. Mantendo-se o exemplo da eleição presidencial do ano de 2014, dados oficiais (TSE) revelam que a candidata Dilma Rousseff foi eleita presidente com 54.501.188 votos, número que representa menos de $30 \%$ da população nacional. $11 \mathrm{Em} 21 / 09 / 2010$, durante a campanha eleitoral daquele ano, foi divulgado o result ado de uma pesquisa encomendada pela Associação dos Magistrados Brasileiros (AMB) em que quase met ade dos eleitores entrevistados revelaram conhecer alguém que já tenha trocado seu voto por benefícios. Mozart Valadares, presidente da AMB à época da pesquisa, externou sua preocupação como relevante número de pessoas que confessaram, publicamente, a venda de votos. Íntegra da notícia disponível em:

<http://eleicoes.uol.com.br/2010/ultimas-noticias/2010/09/21/quase-metade-dos-eleitores-sabe-de-casos- de-compra-devotos.jhtm>. Acesso em: 08.04.2016 
Como se vê, seja pela estrutura do sistema eleitoral, seja pela inoperância do Estado em relação à efetivação dos direitos sociais e da garantia de igualdade entre os indivíduos, o princípio representativo vem se mostrando cada vez menos eficaz em seu propósito: a maioria já não se sente mais representada.

Envoltas por um sentimento de abandono, as pessoas passam a se empenhar mais em descobrir e buscar seus direitos individualmente. À sua espera, encontram o Poder Judiciário, sempre aberto a qualquer pleito que lhe for formalmente dirigido. A voz coletiva que já não é mais respeitada nas instâncias majoritárias, agora se transforma em vozes isoladas diante de magistrados e tribunais.

Razão disto é a sensação coletiva de contrariedade em relação aos rumos adotados pelo Estado (resultado da vontade de uma minoria com maior poder político). Somem-se a esta crise de representatividade as ideias neoconstitucionalistas de supremacia e normatividade da Constituição Federal e ter-se-á uma das principais marcas da democracia contemporânea: a crescente intervenção do Poder Judiciário em temáticas antes entregues aos Poderes eleitos.

Atualmente, o Direito é instrumento pelo qual o homem se representa politicamente - é através do Direito que o homem traduz suas reivindicações e que se organiza administrativamente a sociedade.

A Constituição Federal de 1988 simboliza a travessia de um sistema autoritário de governo para a democratização, marcada pela conscientização coletiva na população acerca de seus próprios direitos. Isto se deu, principalmente, em razão do aumento das garantias individuais e dos remédios constitucionais, revelando o cuidado do constituinte originário em assegurar a efetividade dos direitos ali positivados.

A democracia atual se baseia, também, no simbolismo da Justiça e na possibilidade permanente de sua intervenção. A justiciabilidade atual se sobrepõe à positividade de outrora.

Modernamente, a defesa de interesses individuais e coletivos ganha espaço porque, independentemente do que determina a lei, ela pode ser feita perante um poder 
maior e imparcial. Todo comportamento pode ser submetido ao exame de um terceiro (no caso, juiz) e esta mera eventualidade coloca a todos em estado de constante atenção para com os direitos alheios.

A viabilidade plena e irrestrita de atuação da jurisdição, inclusive contra toda ação ou omissão do Estado, terá como consequência a conversão de quase toda questão política ou social em uma questão judicial. Com isso, a democracia, antes simbolizada pelo Governo, passa a ter lugar na Justiça.

Conforme já evidenciado, o Poder Judiciário tem sua atuação e importância significativamente aumentadas em razão, principalmente, da ineficiência das esferas políticas, assumindo a função de órgão garantidor de voz aos atores sociais - já esquecidos por seus representantes. Aqueles seres "invisíveis" aos demais Poderes encontram na Justiça a possibilidade de serem vistos e compreendidos.

Pode-se defender, então, que o sucesso do Poder Judiciário é proporcional ao descrédito das instituições políticas que, embora sejam tradicionalmente manifestação dedemocracia, já não provêm à sociedade a referência simbólica da representatividade. $\mathrm{O}$ povo já não se enxerga mais nas escolhas políticas daqueles que, em tese, deveriam representar seus interesses.

Diante deste novo contexto, a dimensão coletiva da política e da democracia tende a ser substituída pelo individualismo típico das demandas judiciais. Trata-se, portanto, de uma manifestação mais direta da democracia, na qual os cidadãos (cientes de seus direitos e da possibilidade de exercê-los) controlam melhor sua representação e reivindicam com mais frequência e fervor os seus direitos.

Além disso, a evolução da democracia, que passa a estar cada vez mais ligada à jurisdição, dá a todos os indivíduos a possibilidade de colocar-se perante o Estado, fictamente, em condição de igualdade, fato que assume relevante papel simbólico: cada um e qualquer um pode, perante o Poder Judiciário, derrotar o Estado.

A intervenção crescente do Poder Judiciário como forma de garantir voz aos cidadãos parece ser marca das recentes alterações que se operam na relação entre Estado 
e sociedade. Contrapõe-se ao antigo papel restrito dos magistrados e tribunais (típico do positivismo) e forma uma democracia mais forte, oferecendo mais garantias aos seus cidadãos e indo ao encontro das duas grandes características da democracia: soberania do povo e proteção aos direitos dos indivíduos.

\section{Anseios contramajoritários}

A organização do Estado e a regulamentação das relações sociais são feitas por normas legais emanadas do Poder Legislativo e, excepcionalmente, do Poder Executivo. Ambos Poderes de Estado são compostos por membros eleitos, em sistema majoritário: representam, portanto, a maioria que os elege. Daí dizer-se que tais normas refletem, em verdade, a vontade do povo - ou, pelo menos, da maioria dele.

A partir do momento em que o Poder Judiciário impede ou altera a forma de aplicação de uma norma legal, ele assume um papel contramajoritário, ou seja, seus órgãos e agentes, muito embora não tenham sido investidos por vontade popular (mas porcritério meritório), afastam ou conformam leis elaboradas pelos representantes da maioria do povo.

Corrente ideológica contrária ao ativismo judicial, o passivismo judicial, em respeito à vontade das maiorias políticas, prega que os indivíduos não têm direito contra elas: o Poder Judiciário não pode ignorar a vontade dos Poderes representativos para impor seu próprio ponto de vista.

A sociedade contemporânea é pluralista e, em assim sendo, são habituais os desacordos morais, ou seja, as diferentes concepções sobre um mesmo determinado tema - inclusive daquilo que seja justiça social, da legitimidade das políticas públicas e do conteúdo dos direitos fundamentais.

Parte da doutrina (WALDRON, 1999) entende que, diante de tamanhas e constantes discordâncias, a decisão acerca destas matérias deve ser tomada pelos 
membros da sociedade, que exprimem sua concepção em igualdade de condições e aquela que revelar a vontade da maioria, prevalece.

De acordo com a crítica, ao permitir que questões conflituosas saiam do espectro decisório da sociedade politicamente organizada para encaminhá-las à análise do Poder Judiciário, faz-se prevalecer o ponto de vista de uma elite judiciária contra a qual os verdadeiros interessados (cidadãos) nada podem.

Na cena política nacional contemporânea, todavia, já se duvida da efetividade do princípio majoritário, tachando-se de mito a ideia de que o processo legislativo e a atuação administrativa traduzam fielmente a vontade popular. Os Poderes Legislativo e Executivo, em qualquer esfera de governo, não se mostram eficazmente representativos, desvirtuam a ideia de democracia e se posicionam constantemente descompromissados com os direitos básicos garantidos constitucionalmente.

Se tecnicamente é desaconselhável que o Poder Judiciário possa contrariar aquilo que se tem como determinação da maioria, a atual realidade política e social exige tal atuação. Veja-se, inclusive, que a própria Constituição Federal é constituída de princípios e valores protetores das minorias e garantidores de seus direitos contra eventual domínio da maioria mais forte. Para isto serve a rigidez constitucional: para proteger determinados interesses das decisões majoritárias, servindo como um eficaz mecanismo de proteção das minorias.

De fato, PIRES (2011), afirma que:

“...as maiorias se articulam mais facilmente e de maneira menos custosa; para elas é mais simples obter o que querem/precisam pela via do processo político ordinário. Com as minorias é diferente. Seus objetivos e anseios dificilmente recebem o apoio necessário para se verem vitoriosos ou, muitas vezes, sequer respeitados no ambiente legislativo". 
A jurisdição constitucional, no exercício de sua função de proteger de afrontas o texto da Constituição, deve voltar-se principalmente para resguardar a minoria que, sem poder de defesa de seus interesses, veem-se constantemente excluídas do jogo político. O ativismo judicial e a atuação antimajoritária da Justiça representam, nesse sentido, um verdadeiro combate aos vícios que maculam a representatividade dos demais Poderes.

Isto não significa que o Poder Judiciário deva transformar-se em um fórum político das minorias (PIRES, 2011), que debate e resolve toda e qualquer demanda dos grupos minoritários. Em um regime democrático deve prevalecer, em certo ponto, a decisão das maiorias sobre questões ordinárias sobre a vida social.

Ainda assim, a Justiça não deve sucumbir às determinações majoritárias quando elas esbarram no exercício da autonomia pública ou privada das maiorias, tendo o dever de afastar obstáculos fáticos e/ou jurídicos impostos à minoria que se vê impedida de buscar seus razoáveis projetos de vida. (SOUZA NETO, 2006)

Cabe aqui a nota de que quando se fala em minorias não se está fazendo menção à quantidade de pessoas, mas aos grupos que não compõem a elite política como, por exemplo, os pobres, as donas de casa, os imigrantes, os $\mathrm{LGBTI}^{12}$, os praticantes de determinadas religiões, os estudantes, etc. Trata-se, portanto, de uma expressão de poder e não de uma expressão numérica.

O processo decisório político envolve altos custos e demanda de apoio e organização, fazendo com que determinados grupos mais dispersos (embora numerosos) enfrentem maiores obstáculos para movimentar a máquina política em favor de seus interesses.

Esta perceptível diferença entre a participação no processo deliberativo de grupos poderosos e organizados da participação daqueles sem força política deve ser sempre considerada pelo Poder Judiciário, sob pena de, em nome do que se diz "a vontade da maioria", cometam-se abusos contra os direitos da massa desorganizada.

\footnotetext{
${ }^{12}$ Sigla para lés bicas, gays, bis sexuais, traves tis, transexuais e intersexos.
} 
De acordo com a concepção de Dworkin, uma democracia constitucional tem, obrigatoriamente, duas dimensões: a dimensão política e a dimensão dos princípios (SILVA, 2009). A dimensão política se caracteriza por ser aquela em que os membros da comunidade decidem conjuntamente, e por maioria, os interesses da coletividade. A dimensão dos princípios, por sua vez, é aquela que garante aos indivíduos determinados direitos que não podem ser violados, sequer pela vontade politicamente manifestada.

Explica ainda o autor que tais direitos servem como trunfos dos indivíduos contra atos políticos ou contra a vontade das maiorias circunstanciais que se mostrem ofensivos a tais garantias fundamentais (SILVA, 2009). A possibilidade de controle das decisões majoritárias pelo Poder Judiciário mostra-se, então, como o maior dos direitos: o direito de se ter direitos fundamentais inatingíve is.

A confiança outrora depositada no parlamento transferiu-se, na contemporaneidade, à Justiça, que já se mostra uma instância eficaz de defesa dos direitos das minorias. Daí presumir-se que toda eventual intervenção contramajoritária será, portanto, em defesa das normas fundamentais da Constituição Federal e em favor da democracia.

Em tempos de redemocratização, este vem sendo o grande papel do Poder Judiciário brasileiro: proteger e promover os direitos fundamentais de todos e resguardar as regras do jogo democrático para que as minorias também tenham acesso a ele. No exercício desta sua função, o Judiciário se apresenta às minorias como um meio eficaz e transparente de conseguir proteção contra as determinações das maiorias políticas, especialmente quando elas não refletem a vontade da maioria real(desorganizada e sem força política, mas repleta de anseios legítimos).

Diante desta nítida desconformidade entre a vontade dos grupos politicamente atuantes e o desejo da população que, por falta de informação, organização e despreparo, não participa do processo deliberativo, não lhe resta outra alternativa senão buscar pela defesa de seus interesses em uma esfera de poder na qual possua voz independentemente de condições prévias de difícil cumprimento. 
Este cenário - de desvirtuamento das decisões políticas, que deixam de representar a vontade do povo, e do crescente posicionamento ativista dos tribunais pátrios - faz com que seja cada vez maior a procura pelo Judiciário e, proporcionalmente, o descaso com as instâncias representativas.

\section{CONCLUSÃO}

Diante da ineficácia dos Poderes Executivo e Legislativo em saciar os anseios sociais, o Poder Judiciário (pulverizado e acessível) se mostra como a última alternativa da população, que suplica pela concretização urgente de seus direitos fundamentais.

A injustiça social se apresenta nitidamente aos olhos de quem quiser enxergá-la; está latente no semblante daqueles que dependem do Estado para ter saúde, moradia, condições dignas de trabalho e, por fim, dignidade. Na contramão destas necessidades imediatas caminha o mal funcionamento sistêmico dos serviços públicos e a inoperância dos parlamentares. Diante desta cena, o Poder Judiciário não pode, simplesmente, fechar suas portas.

Se por um lado se deve reforçar a importância funcional do Congresso Nacional e zelar pelo equilíbrio harmônico entre os Poderes do Estado, por outro lado há que se conceder eficácia a uma Constituição Federal que, há décadas, impõe ao Poder Público posturas, ideologias e metas reiteradamente ignoradas. Em um Estado Constitucional Democrático não cabe mais justificar a ineficácia de direitos fundamentais pela inércia dos Poderes Legislativo e Executivo, que permanecem inoperantes frente a um Poder Judiciário engessado pelos estreitos limites de suas funções típicas. Entre a flexibilização procedimental e expansão da atuação dos magistrados (com todos os possíveis desajustes que daí poderão porvir) e a manutenção de um sistema ineficiente e rígido, a escolha é difícil, mas se impõe: há que se cumprir a Constituição Federal ainda que isto represente a ruptura com a postura tradicional.

Postas as circunstâncias atuais, o ativismo judicial merece ser visto como parte da solução, não do problema. Ainda assim, seu uso deve ser eventual e controlado, para se 
afastar o risco de desviar as atenções da verdadeira ameaça que se coloca diante da democracia nacional: a falta de legitimidade e representatividade do Poder Legislativo e do Poder Executivo.

Até que se tenha um Poder Legislativo que responda satisfatoriamente aos pleitos sociais e uma Administração Pública que concretize os direitos constitucionalmente assegurados, a Justiça deverá ter seu espectro de atuação aumentado e deve continuar adotando uma postura mais ativa que a de costume. Os prejuízos advindos da inércia do Poder Judiciário serão, de certo, maiores do que aqueles que podem eventualmente decorrer de sua atuação extraordinária.

\section{REFERÊNCIAS}

BARROSO, Luís Roberto. Constituição, democracia e supremacia judicial: direito e política no Brasil contemporâneo. In: FELLET, André Luiz Fernandes; PAULA, Daniel Giotti de; NOVELINO, Marcelo (orgs.). As novas faces do ativismo judicial. Bahia: JusPodivm, 2011.

FELLET, André Luiz Fernandes; PAULA, Daniel Giotti de; NOVELINO, Marcelo (orgs.). As novas faces do ativismo judicial. Bahia: JusPodivm, 2011.

GRIMM, Dieter. Constituição e política. Belo Horizonte: Del Rey, 2006.

MALUF, Sahid. Teoria geral do Estado. São Paulo: Saraiva, 1998

PAULA, Daniel Giotti de. Uma leitura crítica sobre o ativismo e a

judicialização da política. In:FELLET, André Luiz Fernandes; PAULA,

Daniel Giotti de; NOVELINO, Marcelo (orgs.). As novas faces do

ativismo judicial. Salvador: JusPodivm, 2011.

PIRES, Thiago Magalhães. Pós-positivismo sem trauma: o possível e o indesejável no reencontro do direito com a moral. In: FELLET, André Luiz Fernandes; PAULA, Daniel Giotti de; NOVELINO, Marcelo (orgs.). As novas faces do ativismo judicial. Bahia: JusPodivm, 2011, p. 51.

SILVA, Virgílio Afonso da. O STF e o controle de constitucionalidade: deliberação, diálogo e razão pública. In: Revista de Direito Administrativo 250, 2009. 
SOUZA NETO, Cláudio Pereira de. Teoria constitucional e democracia deliberativa: um estudo sobre o papel do direito na garantia das condições para a cooperação na deliberação democrática. Rio de Janeiro: Renovar, 2006.

WALDRON, Jeremy. Law and Disagreement, Oxford: Clarendon, 1999 